\title{
The Effect of Discovery Learning Model on Social skills And Students' Learning Outcomes of Mycultivation Theme in Fourth Grade of Elementary School
}

\author{
Siska Nur Wahida, M. Bambang Edi Siswanto, Nasution, Suhanadji \\ Universitas Negeri Surabaya \\ Surabaya, Indonesia \\ siskanurwahida@gmail.com
}

\begin{abstract}
This study aims to analyze the effect of discovery learning models on social skills and learning outcomes of fourth grade elementary school students. The research is a quasi-experimental research with pre-post test control group design. The dependent variable in this study is the discovery learning model and the independent variables are social skills and student learning outcomes. Subjects in this study were students in grades IVA and IVB SDN Loceret II Nganjuk with a total of 20 students. Data collection techniques in this study used tests (pre-post test), observation, and documentation. Data analysis techniques in this study used descriptive statistical analysis techniques. The calculation on the data analysis was done with the help of the SPSS 17 computer software program. The results showed that the discovery learning model influences the social skills and student learning outcomes in social studies learning. Discovery learning models influence social skills that indicated by $t$ count $-4,459<t$ table 1,686. Discovery learning models affect student learning outcomes that indicated by tcount of 2.916>t table 1.686 and sig 2 tailed value of $0.006<\alpha(0.05)$. This means that discovery learning models have a significant effect on social skills and social studies learning outcomes.
\end{abstract}

Keywords-Model Discovery Learning, Social Skills, Learning Outcomes.

\section{INTRODUCTION}

Currently, the practice of implementing learning in elementary schools uses thematic learning . Kadir (2014) states that in thematic learning students can build a relationship between one experience with another experience or knowledge with other knowledge or between knowledge and experience so as to enable learning to be interesting (p. 7). Through thematic learning, students are required to be active in learning activities. In addition, students are also required to explore their own sources of information both through their everyday environment and from various technologies. Reform in the field of education begins with the development of approaches or models of learning that will be very useful in the life of the global era. But in reality, there is found the use of conventional models in learning activities in schools. The steps that need to be taken by the teacher is by developing learning models that are able to overcome this reality [1].

According to KTSP (2006), it states that Social Sciences has an important role in developing community life skills and aims to educate students to be individual who think logically and critically, and to be having such curiosity, inquiry, problem solving skill, and skills in social life (p. 575). Along with the development of the age of learning activities in elementary schools, it is necessary to apply innovative learning models . One of the innovations in the application of learning models that need to be done is the Discovery Learning model . Based on observations and initial interviews conducted by researchers, it was found that social studies learning in the classroom still used conventional models that are more tend to teacher-centered. While it is known that many social studies subjects demand students to memorize, resulting on saturation for students. The activity of students during learning is only listening to the explanation from the teacher and recording the things that are considered important. Besides, the material taught has not been linked to the problems that exist around students or not in accordance with the reality of people's lives. Material in social studies learning is expected to provide meaning related to everyday lives as part of community members. The existence of several learning problems will have an impact on the lack of interest and the lack of students' motivation to learn so that learning becomes less meaningful [2].

Through social studies, students are expected to get knowledge, attitude, skills and sensitivity in facing life with the challenges around them. Furthermore, students are expected to be able to take action rationally in solving the social problems they face. In order to develop awareness and sensitivity about social symptoms and problems, social studies learning will involve the participants and their surroundings. At present, the implementation of basic education must be able 
to equip students with knowledge, skills and attitudes (characters). If these three things can be achieved, students will become individuals who have the competence in living in modern times like today. The effort to prepare for this has been implemented through formal and informal education. The nature of this case is in accordance with development model of science and discovery [3].

Discovery learning model is one of the appropriate models in the 2013 curriculum, this model provides an opportunity for students to find their own concepts in learning. Through discovery learning models, students are expected to be independent, critical and having creative attitudes. The discovery learning model directs students to be able to find something through the learning process they carry out. They are not only act as consumers, but are also expected to play an active role, even as actors from the creators of science. Learning discovery model is part of the scientific approach framework. The application of the discovery learning model is carried out in groups so that students' social skills can be improved through the group activities, because students are allowed to work together with the group to solve problems in an investigation activity they do [4] .

The purpose of discovery learning models as teaching and learning models are: (1) the ability to think to be more responsive, careful, and exercise reasoning (critical, analytical, and logical); (2) fostering and developing behaviors of curiousness; (3) develop cognitive, affective, and psychomotor aspects; and (4) developing students' behavior, skills, beliefs in deciding things accurately and objectively. Discovery learning model is another name of the model of the invention. Corresponding with this name, this model directs student to find something they do through a learning process. Students are trained to be a scientist. The discovery learning model is an important component in the constructivist approach that has a long history in the world of education. The idea of discovery learning arises from the desire to give a sense of pleasure to children or students in "finding" something by themselves, and follow the footsteps of scientists . Thus, the discovery learning model is a learning that involves students in the process of mental activities through exchanging opinions, discussing, reading on their own, and trying by themselves. Learning by employing discovery learning models encourage students to think critically and creatively [5].

The role of the teacher is no longer as a supplier of knowledge but the teacher acts more as a motivator, facilitator, and learning manager. In addition, the teacher acts as a mentor by providing opportunities for students to actively learn. Teaching and learning activities take place from teacher oriented to student oriented. In this case, students carry out various activities to gather information, compare, categorize, analyze, integrate, organize materials, and make conclusions as a product of their findings [6].

So it can be concluded that the discovery learning model is a learning model that requires students to be able to find answers through the activities they carry out. Students are directed to become a scientist to be able to find simple things. Discovery learning can be used by all ages, but the most appropriate is for elementary school children. In the learning process that uses discovery learning, students actively explore and investigate with the teachers' guidance [7].

Skills social is important for student to start and maintain social positive relationship with friend, peer, teacher, or environment. Social skills is part from social competence. So it can be concluded that social skills is a tool consisting of the ability to interact, communicate effectively both verbally and non-verbally, the ability to be able to demonstrate good behavior, and the ability to establish good relationships with others as expected [8].

Learn includes a process that ends on its output and outcome. Output leads on results for student to follow learning activity, whereas outcome leads on change of individual behavior from results of study. The result of learning is accomplishment on indicators that have been planned. Indicators can be in the form of ability, skill, and gesture-controlled student. Ability that has been mastered by student on lesson is marked with their behavioral change corresponding with an indicator that desired to be achieved [9].

Sudjana (2011) states that the results of learning is a capabilities by participants student after obtaining experience from the learning process (p. 22). Thereby, a result of learning is also called as level ability in which participants' student follow lesson for period of certain time. Result of learning is results which ends any value by following the learning process. Learning is categorized succeed if the level knowledge of participants student increase [10].

\section{METHOD}

\section{Types of research}

This research is quantitative. Quantitative research is has something to do with numbers, start from data collection, interpretation to the data, as well as drawing the results. The research is experiment design with pre-post test control group design. The experiment research tries to investigate whether there is or no relationship because of the effect comparison between one or more group experiment. It is done by treatment with one or more group comparison which doesn't receive treatment.

\section{Subject and Time of Research}

The subjects of this study were students of SDN Loceret II Nganjuk. The sample used in this study were students of class IVA (experimental class) and IVB (control class), each of which consisted of 20 students. The research was carried out +1 month in the even semester of 2017/2018 school year.

\section{Data collection technique}

Data collection is a way that must be done to find and collect information or facts in such a way, so that it is truly the same as reality or in other words called objective. The data presented is truly in accordance with the reality in the field or the data is factual without being reduced or added. Data 
collection techniques that were used in this study are the test techniques (pre-post t test), documentation (to investigate the list of names of students who are the subject of research and the IPS scores of students in the previous subject), observation (to observe how students solve social problems given by the teacher during a lesson), interview (using discovery learning).

\section{Operational Definition of Research Variables}

Model discovery learning is learning model that governs the teaching so that children acquire the previously unknown knowledge. It is done with learning steps that covers explaining the purpose / preparing students, orienting students on problems, formulating hypotheses, conducting discovery activities, presenting the results of discovery activities, and evaluating discovery activities.

Social skills are the ability of individuals to communicate effectively with others both verbally and nonverbally according to the situation and conditions at the time, where these skills are in term of behavioral learning.

Learning outcomes in this study are interpreted as a change from not knowing to knowing through a learning process that is realized with the level of mastery of a learning material which results are expressed by the results obtained through the test.

\section{Data Analysis Technique}

The data to be analyzed in this study were the pre-test and post-test samples. To test the pre-test and post-test it was used t test analysis. From the data collected by the researcher, it will then be arranged in a raw table, then processed in the finished data that has been prepared and analyzed and a conclusion will be drawn. Data analysis techniques used descriptive statistical analysis. In the descriptive analysis it was first to determine the average data obtained. After that, test the validity and reliability of the data in the trial group. If the research instrument has been valid and reliable, research can be done on the control and experiment class. Data obtained from research in early time will then be tested its homogeneity, normality, and independent sample test. Statistical tests in this study were carried out with the help of SPSS 17 computer software program.

\section{RESULTS AND DISCUSSION}

\section{Result}

Based on the results of the validity test that has been done, it shows that all assessment criteria produce a correlation value with a significance of more than 0.4 with a significance level of less than $5 \%$. It can be said that all items about students' social skills are stated as valid. To analyze the data from the test items, the question items on the variables of social skills was analyzed by using SPSS 17 computer software. The reliability test of the instrument was carried out together with the validity test, because validity and reliability can be done in one activity. The reliability test results are as follows:
Table 1

Social Skills Reliability Test Results

\begin{tabular}{|c|c|}
\hline Cronbach's Alpha & N of items \\
\hline 0,925 & 10 \\
\hline
\end{tabular}

The control class using direct learning on average obtains a value which based on the table above, can be concluded that the instrument with a reliability coefficient of 0.925 is said to have a strong or high level of reliability. In a result, the instrument is included in the category of having a high level of reliability.

Based on the data that has been obtained, the results of pret test of students' social skills is 69.25 with a minimum value of 55 and a maximum value of 85 . On the posttest results, the student gets a value of 75.75 so that it can be seen that there are some students who have not finished learning. As a result, social skills was marked in the experimental class with an average value of 70.5, while the average value of posttest after treatment given to the learning model of discovery learning is 87.5 .

Pretest learning outcomes of students in the control class obtain an average score of 65.5 with a minimum value of 40 and a maximum value of 90 . Posttest learning outcomes of students in the control class obtain an average score of 83 with a minimum value of 60 and a maximum score of 95 . From the results of the pretest there were 16 students which are complete. After following the learning process, all students are declared complete with the criteria of value according to the minimum completeness standard. The test results of students in the experimental class got an average value of 63.25 (pre-test) while the average value of posttest in student learning outcomes after giving treatment the model of discovery learning is 90.75 in the very high category.

The results of the pretest of social skills was analyzed by independent sample $\mathrm{T}$ test obtaining sig 2 tailed at $0.670>\alpha$ (0.05) with t-count of -0.430 . The next step were consulted with t table for the one-party test where t table is $1.686(\mathrm{df}=$ 38) so that $t$-count $<\mathrm{t}$ table, meaning that both samples have no significant differences. There is no difference in the average difference in social skills between the experimental variables and the control variables at the pretest. The results of the analysis of students' social skills after being given a treatment are shown by the independent sample $T$ test. Through the test, sig 2 tailed was obtained at $0,000<\alpha(0,05)$ with $t$ count of 4,459 then the results were consulted with table for one party test where $\mathrm{t}$ table is $1,686(\mathrm{df}=38)$ so that $\mathrm{t}$ count $<\mathrm{t}$ table meaning that the second result shows that there is a difference in the sample. This means that there is a difference in students' social skills in the experimental class by employing learning models of discovery learning with the control class of conventional learning application.

The results of the analysis with independent sample $\mathrm{T}$ test obtained sig 2 tailed at $0.573>\alpha(0.05)$ with $\mathrm{T}$ count of 0.568 . Furthermore, the results of the count are consulted with 
$\mathrm{T}$ table for the one-party test where $\mathrm{T}$ table is $1.686(\mathrm{df}=38)$ so that counts $<\mathrm{t}$ table, meaning that there are no significant differences between the two samples. Based on above findings, it can be stated that there is no difference in student learning outcomes in the experimental class and control class at the pretest. The analysis was carried out by independent sample Ttest and it was obtained sig 2 tailed at $0.006<\alpha(0.05)$ with $t$ count of 2.916. Then $t$ count was consulted with $t$ table for one-party test, where $t$ table is $1.686(\mathrm{df}=38)$ so that $\mathrm{t}$ counts $>t$ table. This means that in both samples, there are significant differences.

\section{Discussion}

The average score of students' social skills at pretest in the control class obtained results of 69.25 and in the experimental class the results were 75.75 . Based on the results of the $t$ test, the results of the $t$ count were 0.430 and $t$ table was 1.686 , so that $\mathrm{t}$ count $<\mathrm{t}$ table $=-0.430<1.686$. On the results of 2-tailed sig of $0.670>\alpha(0.05)$ the $\mathrm{H} 0$ is accepted and $\mathrm{H}$ a is rejected, so there is no difference average value of social skills between the experimental group and control group during the pretest.

The treatment given to students in learning can be seen in the results on the posttest value. The results of the average posttest value of students' social skills in the control class was 75.75 while in the experimental class, it was 87.50 . In the $t$ test results, it is obtained $\operatorname{sig} 2$ tailed at $0,000<\alpha(0,05)$ with $t$ count of $-4,459$ then the results were consulted with $t$ table for one party test where $t$ table $1,686(\mathrm{df}=38)$ so that $t$ count $<\mathrm{t}$ table, meaning that the results of the two samples have differences. So it can be said that $\mathrm{H}_{0}$ is rejected and $\mathrm{H}_{\mathrm{a}}$ is accepted. This shows that there are differences in students' social skills in the control class and experimental class. Based on the analysis, it can be concluded that students' social skills by using discovery learning models is higher than the social skills of students who use conventional learning.

The average value of pretest learning outcomes of students in the control class obtained an average value of 65.50 while in the experimental class obtained an average of 63.25. The test results independent sample $\mathrm{t}$ test result $\mathrm{t}<\mathrm{t}$ table is $0,568<1.686$ while sig 2 tailed results $0573>\alpha(0.05)$ then $\mathrm{H} 0$ is rejected and $\mathrm{H}$ a accepted. This shows that there are differences in student learning outcomes in the control class with the experimental class.

The average posttest score of learning outcomes obtained by students in the control class was 83 , while in the experimental class was 90.75 . The independent sample $t$ test results obtained the $t$ count that equal to 2.916 and $1.686 \mathrm{t}$ table so that $\mathrm{t}>\mathrm{t}$ table $(2.916>1.686)$. In the $\mathrm{t}$ test the sig 2 tailed was 0.006 with $\alpha$ of 0.05 so that $\operatorname{sig}<\alpha(0.006<0.05)$. Decisions was taken on the results of $t$ test where $\mathrm{H}_{0}$ is rejected and $\mathrm{H}_{\mathrm{a}}$ is accepted.

Based on the hypothesis test results, it indicates that there are significant differences between discovery learning model against social skills and students' learning outcomes.
There are different social skills in the experimental class by implementing the discovery learning model compared to conventional learning. The differences in the students' initial abilities before being treated were not so significant. The provision of treatment or treatment by using a model of discovery learning in the experimental class showed better social skills than the control class which were treated by using conventional learning. Learning outcomes of students with learning model of discovery learning also shows better results compared to student learning outcomes using conventional learning.

\section{IV.CONCLUSION}

Based on the discussion on the results of the study it can be concluded that:

1. Learning model of discovery learning has influenced students' social skill. This could seen from the results analysis obtained that $\mathrm{t}$ count $<\mathrm{t}$ table $=-0.430$ $<1.686$. On 2 tailed sig result amounted to $0.670>\alpha$ $(0,05)$ so that there is no difference of average social skill between experiment group with group control at pretest. The treatment given to student on learning could be seen from the results at the posttest that shown sig 2 tailed at $0,000<\alpha(0,05)$ and $t$ count $<\mathrm{t}$ table $(-4,459<1,686)$. It means that the result of second sample was not significantly different. This shows that there is difference students' social skill on class control and class experiment.

2. Learning model of discovery learning takes effect to results on student learning. This could be seen from results analysis that was obtained from $\mathrm{T}$ test that $\mathrm{T}$ count $<\mathrm{t}$ table where $0.568<1.686$ while the result of sig 2 tailed is $0.573>\alpha(0,05)$. This shows that there is a difference result of class control with class experiment. T-test was obtained that $t$ count amounting to 2,916 and t table amounting to 1.686 so $\mathrm{t}$ count $>\mathrm{t}$ table $(2.916>1.686)$. On $\mathrm{t}$-test, it was obtained sig 2 tailed by 0.006 with $\alpha$ equal to 0,05 , so that $\operatorname{sig}<\alpha(0.006<0.05)$. This shows that there is difference result on class control and class experiment. It is then could be concluded that student have good learning results with discovery learning models.

\section{REFERENCES}

[1] H. Akcay and R. E. Yager, "The impact of a science/technology/society teaching approach on student learning in five domains," J. Sci. Educ. Technol., vol. 19, no. 6, pp. 602-611, 2010.

[2] Depdiknas, KTSP. Jember: Depdiknas Jember, 2014.

[3] J. Dostal, "Theory of Problem Solving. Procedia Social and Behavioral Sciences," 2014.

[4] A. Fajar, Portofolio Dalam Pembelajaran IPS. Bandung: Rosdakarya, 2009.

[5] A. Kadir and H. Asrohah, Pembelajaran Tematik. Jakarta: Rajawali Pers, 2014 
[6] G. Kızılkaya and P. Aşkar, "The development of a reflective thinking skill scale towards problem solving. Journal Education and Science," 2009.

[7] J. D. Meyer and R. K. James, STS for Pre-Service Teachers: Does It Translate in the Classroom? Paper presented at the Annual Meeting of the National Association for Research in Science Teaching. New Orleans. LA, 2002.
Education and Training Studies Vol. 5, No. 11. Turkey, 2017.

[10] N. Sudjana, Penilaian Hasil Proses Belajar Mengajar. Bandung: Remaja Rosdakarya, 2011.

[8] A. Poedjiadi, Discovery Learning: Model Pembelajaran Kontekstual Bermuatan Nilai. Cet. 3. Bandung: PT. Remaja Rosdakarya, 2010.

[9] S. Y. Sivaci, The Relationship between Reflective Thinking Tendencies and Social Problem Solving Abilities of Pre-Service Teachers. Journal of 